Edunomika - Vol. 03, No. 01 (Februari 2019)

\title{
ANALISIS MOTIVASI, KOMPETENSI, DAN DISIPLIN KERJA TERHADAP KINERJA GURU DI SMP AL-ISLAM 1 SURAKARTA
}

\author{
Isnarizal Shoim, Eny Kustiyah, Sudarwati \\ Fakultas Ekonomi Manajemen Universitas Islam Batik Surakarta \\ Email: sisnarizal@yahoo.com
}

\begin{abstract}
The purpose of this study was to determine the effect of motivation, competence, and work discipline on teacher performance. This study includes a type of quantitative research that explains the relationship between variables and testing hypotheses. The population in this study were all teachers at Al-Islam 1 Middle School in Surakarta, totaling 63 people. The entire population is taken as a sample. Methods of collecting data using a questionnaire. The data analysis technique uses multiple linear regression analysis. The results of the study show that: (1) Motivation, competence, and work discipline simultaneously have a significant effect on the performance of teachers in Surakarta Al-Islamic Middle School 1. Teacher performance will increase if teachers have high work motivation, good and appropriate teaching competencies, and have high discipline in work; (2) Motivation has a positive effect on teacher performance at Surakarta Al-Islam Middle School. The higher the motivation to teach, the higher the teacher's performance; (3) Competence has a positive effect on teacher performance at Surakarta AlIslam Middle School. The higher the teaching competency, the higher the teacher's performance; (4) Work discipline has a positive effect on teacher performance at Surakarta Al-Islamic Middle School 1. The higher the work discipline, the higher the teacher's performance.
\end{abstract}

Keywords: Teacher Performance, Motivation, Competence, Work Discipline

\section{PENDAHULUAN}

Guru berperan penting dalam pendidikan nasional sehingga berpengaruh terhadap terciptanya proses dan hasil pendidikan yang berkualitas. Guru harus memiliki kinerja utuk mampu memberikan dan merealisasikan harapan dalam membina anak didik (Azwatono, 2014).

Sesuai dengan Pasal 20 UU No 14 Tahun 2005 tentang Guru dan Dosen, bahwa guru harus menjalankan tugas keguruannya di dalam kelas dan tugas kependidikannya di luar kelas, berttanggungjawab mempersiapkan segala kebutuhan pembelajaran (Hafid, 2017).

Hartanti dan Yuniarsih (2018) dalam penelitiannya menyatakan kinerja guru harus terus ditingkatkan. Guru harus berkomitmen untuk terus belajar tentunya di era global yang semua serba cepat, dinamis, dan kompetitif.

Guru termotivasi untuk meningkatkan kualitas pembelajarannya karena adanya dorongan untuk membuat siswa pandai. Guru yang termotivasi dalam mengajar akan menimbulkan kepuasan jika tujuan yang diharapkan tercapai yaitu siswa yang memiliki kompetensi dan berkepribadian baik (Yenny, 2018). Motivasi mengajar jika tidak didukung kompetensi yang memadai dari para guru maka kinerja yang dihasilkan juga tidak tercapai dengan maksimal (Hafid, 2017).

Guru harus memiliki empat kompetensi dasar, yaitu: kompetensi pedagogik (kemampuan dalam mengelola pembelajaran), profesional (penguasaan materi), sosial (kemampuan 
berkomunikasi dan bergaul), kepribadian (pribadi yang dewasa, arif dan bijaksana, dan mampu menjadi teladan) (Turangan, 2017).

Selanjutnya apabila sekolah menginginkan agar kinerja gurunya meningkat, maka usaha yang harus dilakukan sekolah adalah dengan menerapkan disiplin. Kepala sekolah sebagai pihak sentral harus berusaha agar terjadi kedisiplinan dari para guru. Penanaman kedisiplinan sangat penting karena kedisiplinan tersebut dapat menjadi kebiasaan yang positif dan menunjang pencapaian kinerja (Azwatono, 2014).

Permasalahan disiplin kerja yang menghambat kinerja yang masih sering terjadi diantaranya adalah kurangnya kedisiplinan guru terhadap peraturan yang telah ditentukan. Keadaan ini merupakan cermin dimana disiplin kerja yang dimiliki guru masih jauh dari harapan. Ketidakdisiplinan dari segi waktu menunjukkan sikap yang kurang baik diperlihatkan pada peserta didik karena sikap yang baik dimulai dari pendidik terlebih dahulu. Suatu sikap disiplin haruslah diterapkan lewat tingkah laku yang selalu taat terhadap peraturan yang berlaku. Sikap ini diharapkan akan berdampak pada peningkatan kinerja guru itu sendiri serta berdampak pula pada peningkatan mutu dan prestasi peserta didik (Yenny, 2018).

Kondisi ideal motivasi kerja yang tinggi, kompetensi yang memadai, dan displin kerja yang tinggi dari para guru tentunya tidak selamanya bisa berlangsung karena kondisi di lapangan tentang kinerja guru di SMP Al-Islam Surakarta menunjukkan adanya penurunan, beberapa guru datang terlambat, pulang tidak sesuai jadwal, sering menitipkan tugas mengajar kepada guru lain dengan menugaskan siswa untuk mencatat, dan tidak membuat Rencana Pelaksanaan Pembelajaran (RPP).

Berdasarkan latar belakang masalah di atas, maka dilakukan penelitian dengan judul "Analisis Motivasi, Kompetensi, Dan Disiplin Kerja Terhadap Kinerja Guru Di SMP Al-Islam 1 Surakarta".

Merujuk pada uraian latar belakang masalah di atas, maka permasalahan yang diteliti adalah: (1) Apakah motivasi, kompetensi, dan disiplin kerja berpengaruh secara simultan terhadap kinerja guru di SMP Al-Islam 1 Surakarta?; (2) Apakah motivasi berpengaruh terhadap kinerja guru di SMP Al-Islam 1 Surakarta?; (3) Apakah kompetensi berpengaruh terhadap kinerja guru di SMP Al-Islam 1 Surakarta?; (4) Apakah disiplin kerja berpengaruh teradap kinerja guru di SMP Al-Islam 1 Surakarta?

\section{KAJIAN TEORI}

\section{Kinerja Guru}

Mathis dan Jackson (2009: 118), kinerja adalah hasil kerja yang dicapai oleh seseorng atau kelompok orang dalam suatu organisasi, sesuai dengan wewenang dan tanggung jawab masingmasing dalam rangka upaya mencapai tujuan organisasi yang bersangkutan secara legal dan tidak melanggar hukum dan sesuai dengan moral maupun etika.

Kinerja guru adalah prestasi seorang guru dalam merealisasikan perannya sebagai seorang guru. Peran guru dalam pendidikan menunjukkan prestasi dalam kinerjanya. Kinerja guru adalah kegiatan guru dalam proses pembelajaran, melaksanakan kegiatan pembelajaran, dan menilai hasil belajar (Depdiknas, 2008: 16)

Penilaian kinerja guru berkaitan dengan tugas guru dalam melaksanakan tugas keprofesionalannya antara lain: guru berkewajiban merencanakan pembelajaran, melaksanakan proses pembelajaran yang bermutu serta menilai dan mengevaluasi hasil pembelajaran. 


\section{Motivasi}

Definisi motivasi menurut Handoko (2013: 125), motivasi adalah keadaan pribadi seseorang yang mendorong keinginan individu untuk melaksanakan kegiatan-kegiatan tertentu guna mencapai suatu tujuan. Motivasi merupakan kekuatan yang mengendalikan dan menggerakkan seseorang untuk melakukan tindakan atau perilaku yang diarahkan pada tujuan tertentu.

Indikator pengukuran motivasi merujuk pada kombinasi teori motivasi dari Maslow dan Mc. Clelland: Motivasi guru untuk berprestasi, motivasi guru untuk berafiliasi, motivasi guru untuk mendapat penghargaan, dan motivasi untuk beraktualisasi diri

\section{Kompetensi Guru}

Menurut Syah (2010: 231), kompetensi guru adalah kemampuan seorang guru dalam melaksanakan kewajiban-kewajibannya secara bertanggung jawab dan layak. Kompetensi guru adalah seperangkat pengetahuan, ketrampilan, dan perilaku yang harus dimiliki, dihayati, dan dikuasai oleh guru dalam melaksanakan tugas keprofesionalan.

Indikator kompetensi guru: (1) Kompetensi pedagogik adalah kemampuan mengelola pelajaran dan peserta didik; (2) Kompetensi profesional adalah kemampuan penguasaan materi pelajaran secara luas dan mendalam; (3) Kompetensi sosial adalah kemampuan guru untuk berkomunikasi dan berinteraksi secara efektif dan efisien; (4) Kompetensi kepribadian adalah kemampuan kepribadian yang mantap, berakhlak mulia, keteladanan dan kewibawaan.

\section{Disiplin Kerja}

Hasibuan (2012: 193) menyatakan disiplin kerja adalah kesadaran dan kesediaan seseorang menaati semua eraturan perusahaan dan norma-norma sosial yang berlaku. Kesadaran adalah sikap seseorang yang secara sukarela menaati semua peraturan dan sadar akan tugas dan tanggung jawabnya. Jadi, dia akan mematuhi/ mengerjakan semua tugasnya dengan baik, bukan atas pemaksaan. Kesediaan adalah suatu sikap, tingkah laku perusahaan, baik yang terlusin maupun tidak.

Indikator disiplin guru dikatakan baik apabila memenuhi syarat sebagai berikut (Soejono, 2007:67): Datang tepat waktu, tertib dan teratur, mampu memanfaatkan dan menggerakkan perlengkapan secara baik, mengikuti cara kerja yang telah ditentukan, dan memiliki tanggung jawab yang tinggi terhadap pekerjaannya.

\section{Pengaruh Motivasi, Kompetensi, Dan Disiplin Kerja Berpengaruh Secara Simultan Terhadap Kinerja Guru}

Pendekatan yang dapat dilakukan untuk meningkatkan kinerja guru adalah melalui peningkatan motivasi, kompetensi, dan penerapan disiplin kerja bagi guru. Motivasi sebagai suatu kekuatan potensial yang ada dalam diri seseorang guru yang dapat memberikan dorongandorongan untuk melaksanakan kegiatan sesuai dengan tugasnya untuk mencapai sesuatu. Pelaksanaan tugas guru dalam mengajar harus dibekali dengan kompetensi tertentu yang sesuai dengan mata pelajaran yang diampunya. Kompetensi tersebut dibutuhkan agar pelaksanaan tugasnya sebagai pendidik dapat terlaksana dengan baik. Sedangkan penerapan disiplin dalam mengajar adalah agar pembelajaran dilakukan menurut aturan dan norma yang berlaku. Hal ini tentunya memberikan dampak positif terhadap kinerja guru.

Hipotesis yang diajukan adalah: $\mathrm{H}_{1}$ : Diduga motivasi, kompetensi, dan disiplin kerja, berpengaruh secara simultan dan signifikan terhadap kinerja guru di SMP Al-Islam 1 Surakarta; $\mathrm{H}_{2}$ : Diduga motivasi berpengaruh positif dan signifikan terhadap kinerja guru di SMP Al-Islam 1 Surakarta; $\mathrm{H}_{3}$ : Diduga kompetensi berpengaruh positif dan signifikan terhadap kinerja guru di 
SMP Al-Islam 1 Surakarta; $\mathrm{H}_{4}$ : Diduga disiplin kerja berpengaruh positif dan signifikan terhadap kinerja guru di SMP Al-Islam 1 Surakarta.

\section{METODE PENELITIAN}

Jenis penelitian deskriptif kuantitatif dengan pendekatan survey dengan memberikan kuesioner dan pengolahan data statistik. Populasi penelitian adalah seluruh guru di SMP AlIslam 1 Surakarta yang berjumlah karyawan total 63 orang. Seluruh populasi diambil sebagai sampel. Teknik pengambilan sampel menggunakan total sampling atau penelitian populasi. Jenis data yang digunakan adalah data kuantitatif yang berupa angka-angka. Sumber data primer diperoleh langsung dari para guru di SMP Al-Islam 1 Surakarta sebagai responden menggunakan metode survey dengan kuesioner. Selain kuesioner juga digunakan observasi, dokumentasi, dan studi pustaka. Analisis data menggunakan analisis regresi ganda.

\section{HASIL PENELITIAN}

Hasil analisis data pengaruh motivasi, kompetensi, dan disiplin kerja terhadap kinerja guru menggunaan analisis regresi gandadiperoleh hasil sebagai berikut:

Tabel 1 Hasil Analisis Regresi

\begin{tabular}{lrrr}
\hline & Koefisien & $\mathrm{t}_{\text {hitung }}$ & p-value \\
\hline Konstanta & 5,638 & & \\
Motivasi & 0,248 & 4,694 & 0,000 \\
Kompetensi & 0,455 & 5,511 & 0,000 \\
Disiplin kerja & 0,201 & 4,065 & 0,000 \\
\hline \hline Adjusted $\mathrm{R}^{2}$ & 0,608 & & \\
F Statistik & 30,470 & & 0,000 \\
\hline
\end{tabular}

Berdasarkan hasil analisis regresi dapat disusun persamaan sebagai berikut: $Y=5,638+$ 0,248. $X_{1}+0,455 \cdot X_{2}+0,201 . X_{3}$. Persamaan menunjukkan bahwa kinerja guru dipengaruhi oleh motivasi, kompetensi, dan disiplin kerja guru. Konstanta (a) $=5,638$, berarti jika skor variabel motivasi, kompetensi, dan disiplin kerja konstan, maka skor kinerja guru akan bernilai positif. Koefisien $\left(b_{1}\right)=0,248$, jika motivasi meningkat satu poin, maka kinerja guru akan meningkat (dengan asumsi variabel kompetensi dan disiplin kerja konstan). Koefisien $\left(b_{2}\right)=0,455$, jika kompetensi meningkat, maka kinerja guru akan meningkat (dengan asumsi variabel motivasi dan disiplin kerja konstan). Koefisien $\left(b_{3}\right)=0,201$, berarti jika disiplin kerja meningkat, maka kinerja guru akan meningkat (dengan asumsi variabel motivasi dan kompetensi konstan).

\section{Pengaruh motivasi, kompetensi, dan disiplin kerja secara simultan terhadap kinerja guru SMP Al-Islam 1 Surakarta}

Berdasarkan hasil uji hipotesis dengan uji $F$ diperoleh nilai $F_{\text {hitung }}>F_{\text {tabel }}(30,470>2,76)$ diterima pada taraf signifikansi $5 \%$, maka hipotesis penelitian dinyatakan diterima, yaitu variabel motivasi, kompetensi, dan disiplin kerja secara bersama-sama atau secara simultan berpengaruh signifikan terhadap kinerja guru. Artinya kinerja guru akan meningkat jika guru memiliki motivasi kerja yang tinggi, kompetensi mengajar yang baik dan sesuai, serta memiliki disiplin tinggi dalam bekerja.

Hasil pengujian hipotesis tersebut sesuai dengan pendapat Wibowo (2012: 74) bahwa faktor faktor yang mempengaruhi kinerja guru di antaranya adalah personal factor (faktor 
pribadi) yang ditunjukkan oleh tingkat keterampilan, kompetensi yang dimiliki, motivasi dan komitmen individu, sedangkan faktor situasional ditunjukkan dengan adanya iklim kedisiplinan kerja dalam lingkungan kerja. Diperkuat dengan pendapat Mathis dan Jackson (2009: 183) bahwa faktor-faktor kinerja indidual adalah kompetensi individual, usaha, motivasi, etika kerja, kehadiran dan disiplin kerja, dan pelaksanaan tugas.

Dapat dinyatakan bahwa kinerja guru dapat ditingkatkan dengan pemberian motivasi, peningkatan kompetensi, dan memperketat kedisiplinan guru. Sebaliknya jika terjadi fenomena penurunan kinerja guru, hal ini bisa disebabkan karena tingginya jumlah ketidakhadiran guru untuk mengajar (kurang disiplin), belum optimalnya kompetensi guru, dan rendahnya dorongan guru untuk berprestasi dalam kerja.

\section{Pengaruh motivasi terhadap kinerja guru SMP Al-Islam 1 Surakarta}

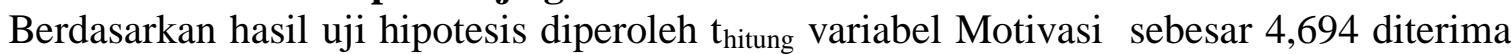
pada taraf signifikansi 5\%. Artinya variabel motivasi berpengaruh terhadap kinerja guru. Semakin tinggi motivasi mengajar, maka semakin tinggi kinerja guru.

Penerimaan hipotesis tersebut sesuai dengan pendapat Mangkunegara (2009: 89), bahwa motivasi berperan penting dalam peningkatan kinerja, yaitu menggerakkan seseorang secara terarah untuk mencapai tujuan pendidikan. Merujuk pada pendapat Mc. Clelland dalam Handoko (2013: 161) motivasi yang menggerakkan seseorang didorong oleh kebutuhan-kebutuhan yaitu kebutuhan akan prestasi, kekuasan, dan afiliasi dengan lingkungan.

\section{Pengaruh kompetensi terhadap kinerja guru SMP Al-Islam 1 Surakarta}

Berdasarkan hasil uji hipotesis diperoleh $\mathrm{t}_{\text {hitung }}$ variabel Kompetensi sebesar 5,511 diterima pada taraf signifikansi 5\%. Variabel kompetensi berpengaruh terhadap kinerja guru. Semakin tinggi kompetensi mengajar, maka semakin tinggi kinerja guru.

Penerimaan hipotesis tersebut sesuai dengan pendapat Mangkunegara (2009: 89), bahwa di antara beberapa faktor yang mempengaruhi kinerja guru salah satunya faktor kemampuan (kompetensi). Guru yang terampil dan kompeten akan lebih mudah dalam mencapai kinerja. Oleh karena itu, guru harus diberi tugas sesuai dengan keahliannya di mata pelajaran tertentu. Dengan penempatan guru yang sesuai dengan bidang keahliannya maka dapat membantu dalam efetivitas suatu pembelajaran.

Guru yang berkompeten mampu menjasdi pendidik profesional untuk mendidik, mengajar, melatih, mengarahkan, membimbing, dan menilai peserta didik. Jika kompetensi tersebut dijalankan dengan baik maka kinerja guru akan meningkat.

\section{Pengaruh disiplin kerja terhadap kinerja guru SMP Al-Islam 1 Surakarta}

Berdasarkan hasil uji hipotesis diperoleh $t_{\text {hitung variabel Disiplin kerja sebesar } 4,065}$ diterima pada taraf signifikansi 5\%. Disiplin kerja berpengaruh terhadap kinerja guru. Semakin tinggi disiplin kerja, maka semakin tinggi kinerja guru.

Penerimaan hipotesis tersebut sesuai dengan pendapat Hasibuan (2012: 194) bahwa kedisiplinan menjadi fungsi operasional manajemen sumber daya yang sangat penting karena tanpa disiplin yang baik, sulit bagi sebuah organisasi untuk mencapai hasil yang optimal.

Tindakan disiplin bila dilakukan secara terus-menerus akan menjadi kebiasaan yang tertanam dan membantu tercapainya tujuan kerja. Sebaliknya ada suatu kondisi yang mana peraturan dan sikap pimpinan yang tidak tegas yang membuat beberapa guru mengabaikan tanggung jawabnya misalnya kedisiplinan dalam membuat perangkat pembelajaran atau tugastugas lain yang dilalaikan. Guru terlambat sering kali diampuni sehingga berulang kali dilakukan 
tanpa ada tindakan tegas sehingga menghambat pekerjaan yang lain. Ini jika dibiarkan akan menghambat pencapaian kinerja organisasi secara keseluruhan.

\section{KESIMPULAN}

Berdasarkan hasil penelitian dan pembahasan yang telah dilakukan, maka dapat diambil kesimpulan sebagai berikut: (1) Motivasi, kompetensi, dan disiplin kerja secara simultan berpengaruh signifikan terhadap kinerja guru di SMP Al-Islam 1 Surakarta. Kinerja guru akan meningkat jika guru memiliki motivasi kerja yang tinggi, kompetensi mengajar yang baik dan sesuai dengan karakteristik mata pelajaran yang diampu, serta memiliki disiplin tinggi dalam bekerja; (2) Motivasi berpengaruh terhadap kinerja guru di SMP Al-Islam 1 Surakarta. Semakin tinggi motivasi mengajar yang dimiliki guru, maka semakin tinggi kinerja guru; (3) Kompetensi berpengaruh terhadap kinerja guru di SMP Al-Islam 1 Surakarta. Semakin tinggi kompetensi mengajar yang dimiliki guru, maka semakin tinggi kinerja guru; (4) Disiplin kerja berpengaruh terhadap kinerja guru di SMP Al-Islam 1 Surakarta. Semakin tinggi disiplin kerja yang dimiliki guru, maka semakin tinggi kinerja guru.

\section{DAFTAR PUSTAKA}

Anam, Chairul. 2018. Pengaruh Motivasi, Kompetensi, Kepemimpinan, Lingkungan Kerja dan Disiplin Kerja Terhadap Kinerja Guru di Sekolah Menengah Kejuruan. Jurnal Manajemen dan Pendidikan Islam, Vol. 4, No. 1, Juni 2018

Azwatono, Epi. 2014. Pengaruh Kompetensi Profesional Dan Kedisiplinan Terhadap Kinerja Guru Dimediasi Motivasi (Studi Pada Guru Smp Negeri Se-Kecamatan Taman Kabupaten Pemalang). Jurnal Program Pascasarjana Universitas Stikubank

Hafid, Moh. 2017. Pengaruh Motivasi Dan Kompetensi Guru Terhadap Kinerja Guru Sekolah Dan Madrasah Di Lingkungan Pondok Pesantren Salafiyah Syafi'iyah Sukorejo. JPII Volume 1, Nomor 2, April 2017

Handoko, Hani T. 2013. Manajemen Personalia dan Sumber Daya Manusia. Yogyakarta: BPFE UGM

Hartanti, Astrid Setianing dan Tjutju Yuniarsih. 2018. Pengaruh Kompetensi Profesional Guru Dan Motivasi Kerja Terhadap Kinerja Guru Di Sekolah Menengah Kejuruan. Jurnal Pendidikan Manajemen Perkantoran Vol.1_No.2 Januari 2018

Hasibuan, Malayu. 2012. Manajemen Sumber Daya Manusia. Jakarta : PT. Bumi Aksara

Mangkunegara, A.A. 2009. Manajemen Sumber Daya Manusia, Cetakan Ke Tujuh. Bandung: PT. Remaja Rosdakarya

Mathis L Robert Dan Jackson John. 2009. Manajemen Sumber Daya Manusia. Jilid 10. Jakarta: Salemba Empat

Siagian, Sondang P. 2015. Teori Motivasi dan Aplikasinya. Jakarta: Rineka Cipta

Turangan, Jeine K. 2017. Pengaruh Kompetensi, Disiplin Kerja dan Profesionalisme Terhadap Kinerja Guru. Jurnal EMBA Vol.5 No.2 Juni 2017 
Isnarizal Shoim, dkk / Edunomika Vol. 03, No. 01 (Februari 2019)

Wibowo. 2012. Manajemen Kinerja. Jakarta : PT Raja Grafindo Persada.

Yenny. 2018. Pengaruh Kompetensi, Motivasi Dan Disiplin Kerja Terhadap Kinerja Guru Pada Yayasan Pendidikan Imanuel Palu. Jurnal Katalogis, Volume 6 Nomor 2 Februari 2018 